\title{
The Critical Role of Economic Assumptions in the Evaluation of Federal Budget Programs
}

\author{
KEITH M. CARLSON
}

W

HEN the Reagan administration announced its budget program in January this year, the projected deficits caused considerable public consternation. Near-term deficits were record-setting in magnitude and persistently large deficits loomed far into the future. The administration's January 1983 budget projections included a deficit of $\$ 225$ billion (including offbudget outlays) for fiscal year 1983 and $\$ 157$ billion in 1986. Without a proposed contingency tax plan, the administration estimated the fiscal 1986 deficit would be $\$ 203$ billion. $^{1}$

One problem inherent in evaluating prospective federal budgets is that receipts and outlays and, thus, the surplus or deficit depend crucially on the performance of the economy. This problem is magnified in a $\$ 3.2$ trillion economy in which public attention still focuses on the nominal magnitude of the federal deficit. A decline of just one or two percentage points in the annual rate of real growth can add billions of dollars to the federal deficit.

The administration's January budget projections reflect both modifications of previous proposals and changes in economic assumptions. As a result, it is difficult to distinguish between the effect of the economy and the effect of policy shifts on the budget. Yet, if analysts wish to determine the extent to which policy changes are responsible for the changes in federal budget projections, the effect of changes in economic assumptions on the federal budget must first be identiffed.

${ }^{1}$ Since this article was prepared, the administration revised its estimate for fiscal 1986 to $\$ 139$ billion. Without the contingency tax plan, the revised estimate would be $\$ 185$ billion. See Office of Management and Budget, Mid-Session Reviston of the 1984 Budget (July 1983).
To illustrate the critical role of economic assumptions, this article assesses the extent to which they are responsible for the differences between President Reagan's initial March 1981 budget and the January 1983 budget. $^{2}$

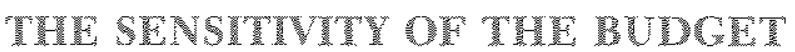 TO TCONOMIC ASSUMPTIONS}

In recent years, the importance of economic assumptions in the process of preparing budget projections has grown. The last three budget documents contained sections on the sensitivity of the budget to economic assumptions. Yet, one of the best discussions of this interrelationship is still the 1962 Annual Report of the Council of Economic Advisers (CEA).

\section{The Origmi 1962 CDA Anulgsis}

The 1962 CEA developed a measure of discretionary fiscal action; at that time it was called the full-employment surplus. ${ }^{3}$ This measure was developed because of

\footnotetext{
${ }^{2}$ The conclusions of the article are not affected by the July 1983 revisions of the budget or of the GNF acoounts.

${ }^{3}$ For a recent discussion of the full-employment (now called "highemployment") surplus, see Frank de Leeuw, Thomas M. Holloway, Darwin G, Johnson, David S. McClain and Charles A. Waite, "The High-Employment Budget: New Estimates, 1955-80," Survety of Current Business (November 1980), pp. 13-43; Frank de Leeuw and Thomas M. Holloway, "The High-Employment Budget: Revised Estimates and Automatic Intlation Effects," Survey of Current Business (April 1982), pp. 21-33; William Fellner, "The High-Employment Budget and Potential Output: A Critique, "Survey of Current Business (November 1982), pp. 26-33; Frank de Leenw and Thomas M. Followay, "The HighEmployment Budget and Potential Output: A Response," Survey of Current Business (November 1982), pp. 33-35.
} 
the ambiguity associated with using the actual surplus or deficit as a measure of fiscal policy actions. The actual surplus or deficit depends on both the budget program and the state of the economy. Although the budget program fixes tax rates and expenditure programs, actual receipts and outlays vary automatically with economic activity. According to the 1962 CEA,

To interpret the economic significance of a given budget it is, therefore, essential to distinguish the automatic changes in revenues and expenditures from the discretionary changes which occur when the government varies tax rates or changes expenditure programs. ${ }^{4}$

Figure 1 illustrates the reasoning behind the development of the full-employment surplus as a measure of discretionary fiscal action. On the horizontal axis is real gross national product (GNP); on the vertical axis is the dollar amount of the federal surplus or deficit. ${ }^{5}$ Each budget line represents a fixed schedule of tax rates and expenditure programs with each line showing how the actual surplus or deficit depends on the level of real GNP. Given the U.S. tax structure, receipts increase with real economic activity, while outlays, which are sensitive to unemployment, tend to decrease with increases in real activity; thus, each budget line is upward sloping with respect to real GNP. Shifts of the budget line represent the action of policymakers on the budget, while movements along a budget line represent the effect of the economy on the budget. ${ }^{6}$ Thus, for example, the budget line would shift from $A$ to $B$ if government outlays were increased or taxes reduced.

The advantage of using the analysis in figure 1 to compare different budget programs is that it separates the effect of the economy from the effect of the policymaker on the budget. Using figure 1 , the 1962 CEA would have interpreted budget $B$ as more expansionary than budget $A$; since, for example, government outlays are higher for budget $\mathrm{B}$, a smaller share of full-employment real GNP is available for private purchase. Thes, full employment is easier to maintain because less private demand is required. Alternative-

\footnotetext{
${ }^{4} 1962$ Economic Report of the President, which also includes the 1962 Ammal Report of the Council of Economic Advisers, pp. $78-79$

${ }^{5}$ This differs slightly from the figure drawn in the 1962 CEA Report (p. 79). The CEA figure had the tutilization rate actual GNP as a percent of potential GNP) on the horizontal axis and the surplus defieit as a percent of potential GNP on the vertical axis. To simplify the analysis here, dollar amounts are used on both axes.

${ }^{6}$ The purpose of the high-employment budget is to capture shifts of the badget line. This is done by focusing or the change in the surplus or deficit corresponding to a level of real CNP consistent with full employment of resources.
}

Figure 1

\section{Economic Activity at the Federal Budget}

\section{Surplus/Deficit \\ Billions of dollars}

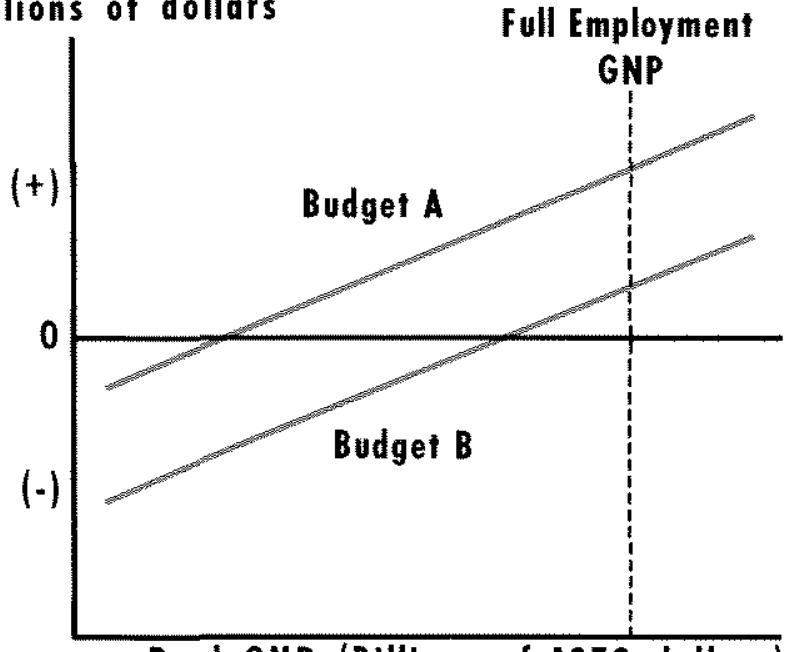

Real GNP (Billions of 1972 dollars)

Shifts of the budget line indicate program shifts. Movements along the budget line indicate the automatic effect of changes in real GNP on the surplus or deficit. Changes in the surplus or defticit at full employment are a measure of program shift.

ly, inflation is more difficut to avoid because there are fewer goods and services to meet private demand. The figure illustrates clearly the pitfalls in assessing the economic impact of the budget by examining the surplus or deficit alone without regard for the level of economic activity.

\section{An Lxtended Analysis}

The 1962 CEA analysis provides a useful starting point for analyzing budget policy in the 1980s. The analysis requires extension, however, in light of inflationary developments over recent years. This analysis is summarized in the schematic diagram on page 8 and figure 2 , which focus on the determination of federal receipts and outlays.

Receipts - Given a structure of tax rates, the most important determinant of federal receipts is nominal GNP (see diagram). Most federal taxes are tied to bases that are sensitive to the movements of nominal GNP. Federal taxes are classified according to source: individual income, corporate income, social insurance, excise, and other. The most relevant bases for these tax. sources are personal income, wages and salaries, 
Figure 2

\section{Economic Activity and the Federal Budget: An Extended Analysis}

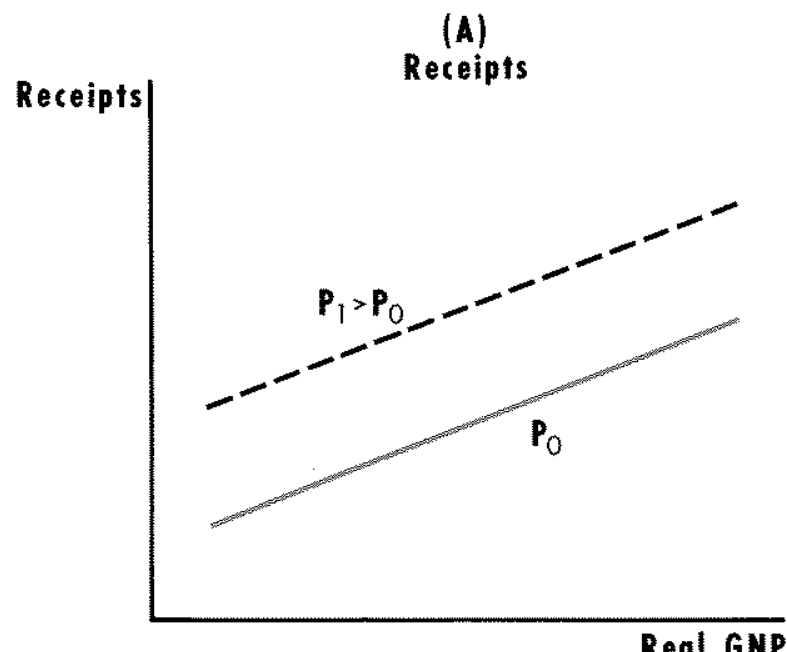

(B)

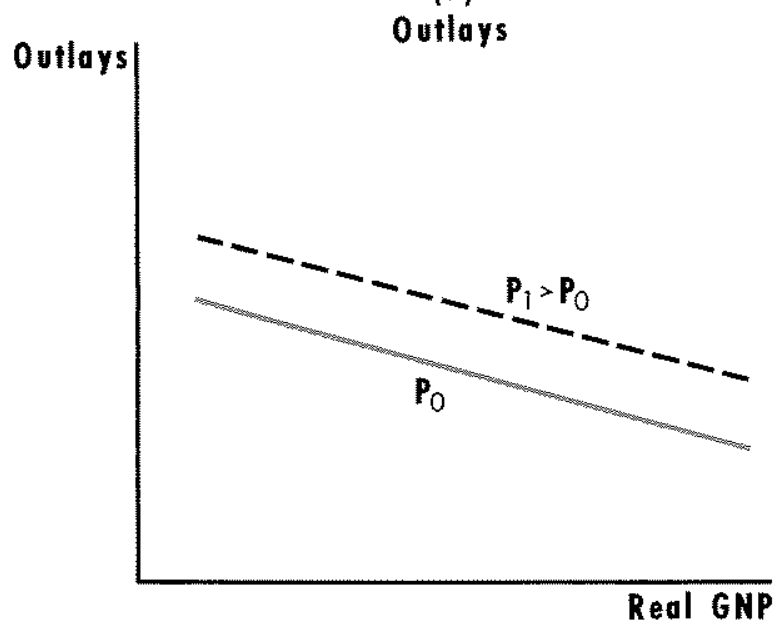

(C)

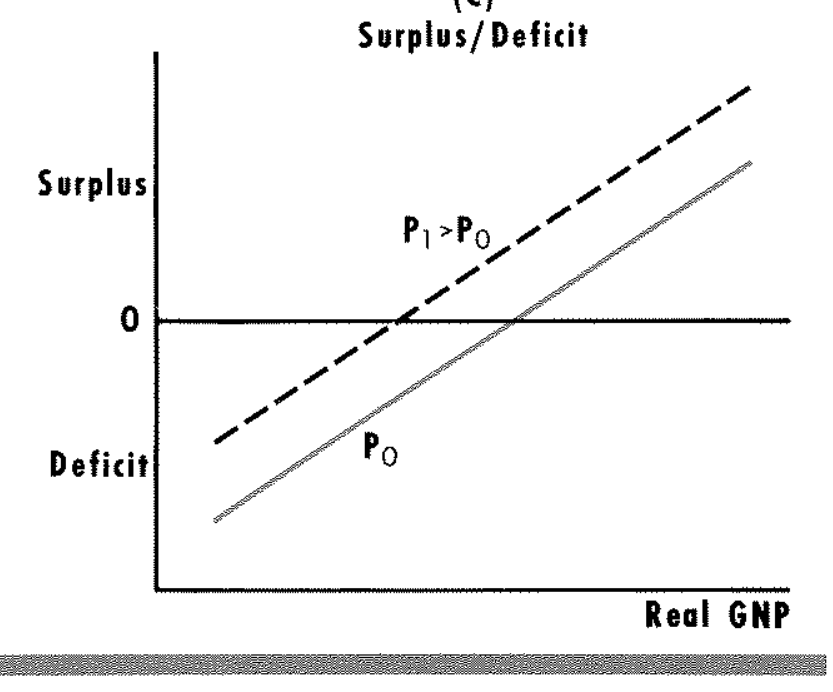

corporate profits and sales. Each of these measures, in turn, moves closely with nominal GNP. A change in nominal GNP is translated quickly into a change in receipts in the same direction, largely because of the U.S. system of withholding and estimated payments.

The determination of federal receipts is shown in panel a of figure 2. Real GNP is plotted on the horizontal axis and receipts on the vertical axis. The dependence of receipts on nominal GNP is captured by drawing a different receipts line for each price level. Thus, with real GNP on the horizontal axis, the level of the receipts line is determined by the structure of tax rates and the price level. A policy change - that is, an increase (decrease) in tax rates - would be shown as an upward (downward) shift of the receipts line with prices unchanged. The effect of economic activity on receipts would be shown either as a movement along the receipts line or a shift because of a change in the price level. A higher price level will shift the receipts line upward; more receipts are collected at each level of real GNP because nominal GNP is higher as a result of a higher price level.

Outlays - Outlays (other than net interest) depend on both the price level and real GNP, but the response is different than for receipts (see schematic diagram). Price level effects on outlays have become more important in recent years as an increasing number of programs become indexed to the cost of living. Although social security is probably the best known of these programs, many other programs are now more or less automatically adjusted to offset price level changes. Changes in programs like Medicare and food stamps, in part, have reflected attempts to maintain program levels in response to changes in the price level.

In addition to programs that are adjusted automatically to changes in the price level, there are many government programs for which Congress makes discretionary changes to reflect changes in the price level. The most important program falling into this category is defense spending.

Besides the price level effects cited above, real economic activity also has an automatic effect on outlays. For the most part, this operates via the effect on unemployment: a reduction in real GNP or its rate of growth tends to increase unemployment and boosts expenditures for unemployment-sensitive programs. ${ }^{7}$

\footnotetext{
"This relationship between changes in real GNP and the unemployment rate is called Okun's law. See Arthur M. Okun, "Potential GNP: Its Measurement and Significance," 1962 Procedings of the Business and Economic Statistics Section of the American Statistical Association, pp. 98-104.
} 


\section{Schematic Diagram of Budget Determination}

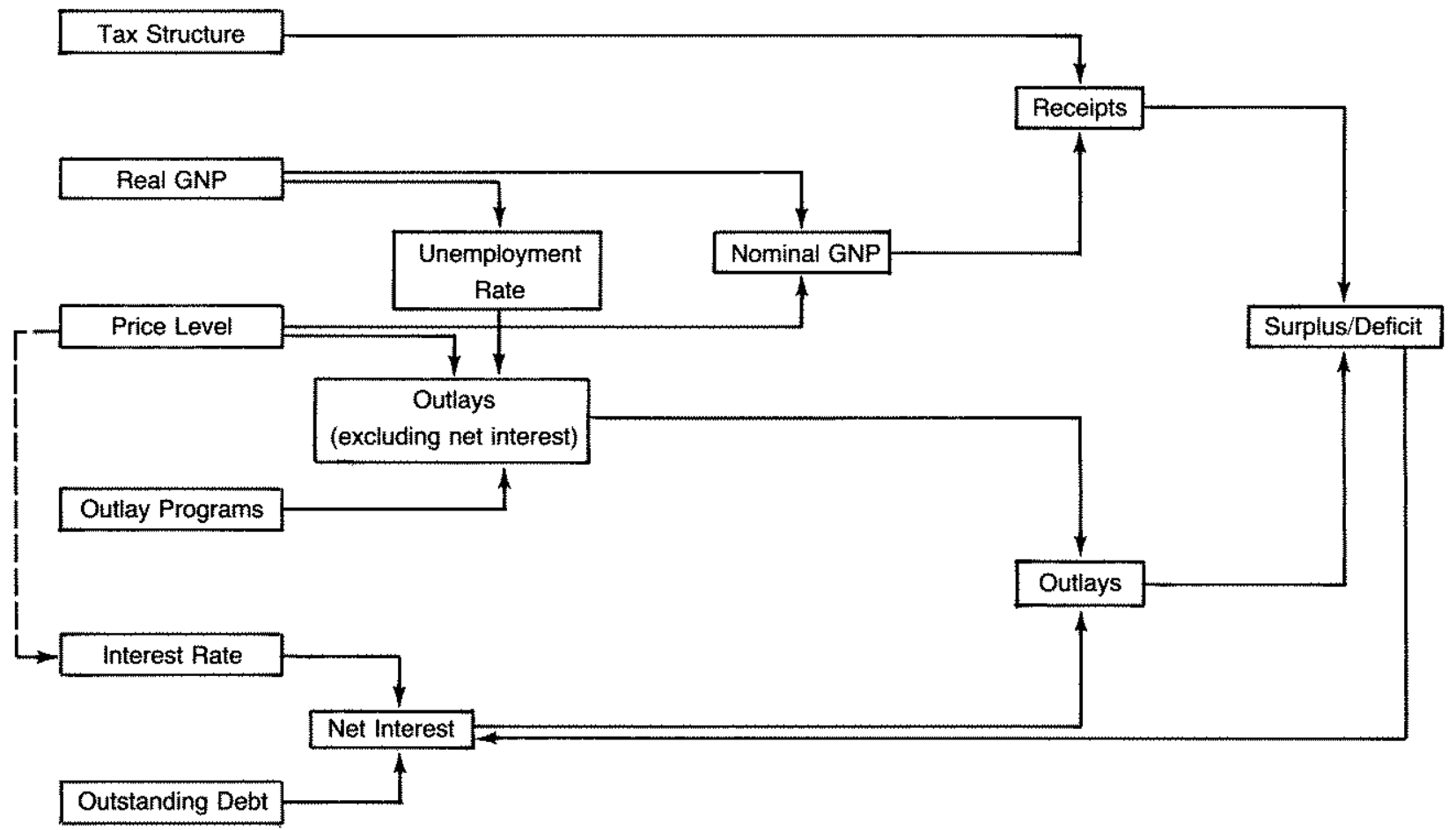

Although outlays for unemployment compensation are the best known of such programs, other types of expenditures are also affected by a slowing of real growth and rising unemployment. Among these are public assistance, food stamps and social security.

As shown in the schematic diagram, outlays are divided into two components: outlays other than interest and net interest. The reason for this division is that the determining factors operate differently. Net interest is singled out for special treatment because it depends on the interest rate and the amount of debt to be financed. The amount of debt to be financed, in turn, depends on the amount of debt inherited from earlier periods as well as the amount of the current surplus or deficit. Interest rate assumptions are a function of the rate of change of the price level rather than the level itself.

This complicated interaction of factors makes it difficult to generalize about the effect of economic assumptions on outlays. Nevertheless, panel b of figure 2 is an attempt to clarify the nature of the relationships.
If the outlay line is interpreted as outlays other than net interest, the analysis is straightforward. The determination of federal outlays is shown graphically in panel $b$ of figure 2. Real GNP is charted on the horizontal axis and the dollar amount of outlays is charted on the vertical axis. The level of the outlay line is determined by the price level and by laws and programs relating to outlays. The line is downward sloping because an increase in real GNP reduces unemploymentsensitive outlays. The effect of a higher price level is to shift the outlay line upward. Outlays other than net interest will be greater for each level of real GNP because of indexed programs.

If, on the other hand, outlays are defined to include net interest, the effect of an increase in the price level on the outlay line is not unambiguously upward. For a given level of real GNP, an increase in the price level increases receipts. If the receipts effect is stronger than the outlay effect, the deficit declines (or the surplus increases), requiring a smaller amount of interest to be paid. Consequently, whether the outlay line shifts up 
or down in response to a change in the price level depends on the relative strength of the effect via non" interest outlays vs. the effect via the deficit and net interest.

Surplus/deficit - Panel c of figure 2 summarizes the net effect of factors determining receipts and outlays. With real GNP plotted on the horizontal axis and the surplus/deficit plotted on the vertical axis, the general appearance of the budget line is the same as figure 1 . For a given fiscal program, an increase of real GNP results in a smaller deficit or larger surplus; an increase of real GNP increases receipts and reduces outlays. There is no ambiguity about the slope of the budget line when drawn with real GNP on the horizontal axis.

The nature of the response of the budget line to changes in the price level is a different matter. Whether the budget line shifts up or down depends on the relative shifts of the receipts and outlay lines. Receipts shift unambigously upward in response to a higher price level, but the effect on outlays is ambiguous. If there are a large number of indexed programs and the cost-of-living escalators are generous, or if a large number of discretionary programs are adjusted to price level changes, the upward shift of the outlay line could exceed that of the receipts line, leading to a downward shift of the budget line. Determining the effect of price level assumptions on the surplus or deficit is thus an empirical matter.

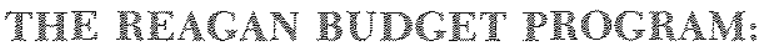 1081 19. 1983}

To illustrate the interaction of economic assumptions and budget projections, projections for fiscal year 1986 from the Reagan budgets of March 1981 and January 1983 are examined. The focus is on fiscal 1986 for several reasons: (1) a long horizon allows the effect of alternative assumptions to be brought into sharper focus; (2) most of the concern about the size of the budget deficit emphasizes the "out years," and thus approximates what the administration calls a "structural deficit"; (3) focusing several years out on the planning horizon, the full effect of the administration's budget program is captured.

The economic assumptions underlying the two Reagan budgets are summarized in table 1 . The levels of GNP differ from those published in the relevant budget documents because of data revisions in the 1981-83 period. All GNP data in table 1 have been recalculated to be consistent with data as reported in early 1983.

\section{篦conomic Assumpions}

The GNP assumptions are presented in terms of both levels and rates of change. Normally, rates of change are more relevant. The levels of GNP are presented as well, however, because with a projection period of six years, small differences in rates of change can accumulate into significant differences in the levels.

As shown in table 1 , the estimates of nominal GNP have been scaled down since 1981. The 1986 GNP estimate from the 1981 budget was $\$ 5,071$ billion; the 1983 budget revised this estimate downward to $\$ 4,366$ billion. In large part, this revision occurred because actual 1982 GNP turned out to be considerably below the projection made in 1981. The budget impact of this revised assumption is illustrated by assuming an average tax rate of 20 percent. With no change in tax laws (from late 1980), the effect of revised assumptions since early 1981 would be to reduce tax collections in 1986 by $\$ 140$ billion $[(4,336-5,071) \times$ $.20]$.

In 1981, the Reagan administration was very optimistic about future levels of real GNP. Real GNP for 1986 was projected at $\$ 1,873$ billion (1972 dollars). In January 1983, this projection was revised downward to $\$ 1,707$ billion. Over $\$ 100$ billion of this revision was attributable to the overestimate of 1982 real GNP.

Price level estimates have also been scaled back since 1981 . The 1981 budget projected the 1986 price level at $271.0(1972=100)$. The lower-than-expected price level in 1982 produced a downward revision of projected price trends throughout the 1983-86 period.

Unemployment assumptions go hand-in-hand with the real growth assumptions. The administration's forecast of unemployment for 1986 was 5.6 percent. The 1983 budget jumped the unemployment assumption to 8.0 percent, reflecting both the sharp drop of real GNP in 1982 and the downward revision of the 1983-86 projections of real GNP.

Interest rate assumptions usually reflect inflation rates, but the assumptions shown in table 1 generally are not consistent with that relationship. In March 1981, the Reagan administration began with an optimistic outlook for interest rates for the long term, but the high interest rates of 1981 and 1982 led to a sharp upward revision in January 1983. Consequently, between 1981 and 1983 interest rate projections were increased even though projected inflation rates were reduced. 


\section{Table 1}

\section{Economic Assumptions of the Reagan Administration}

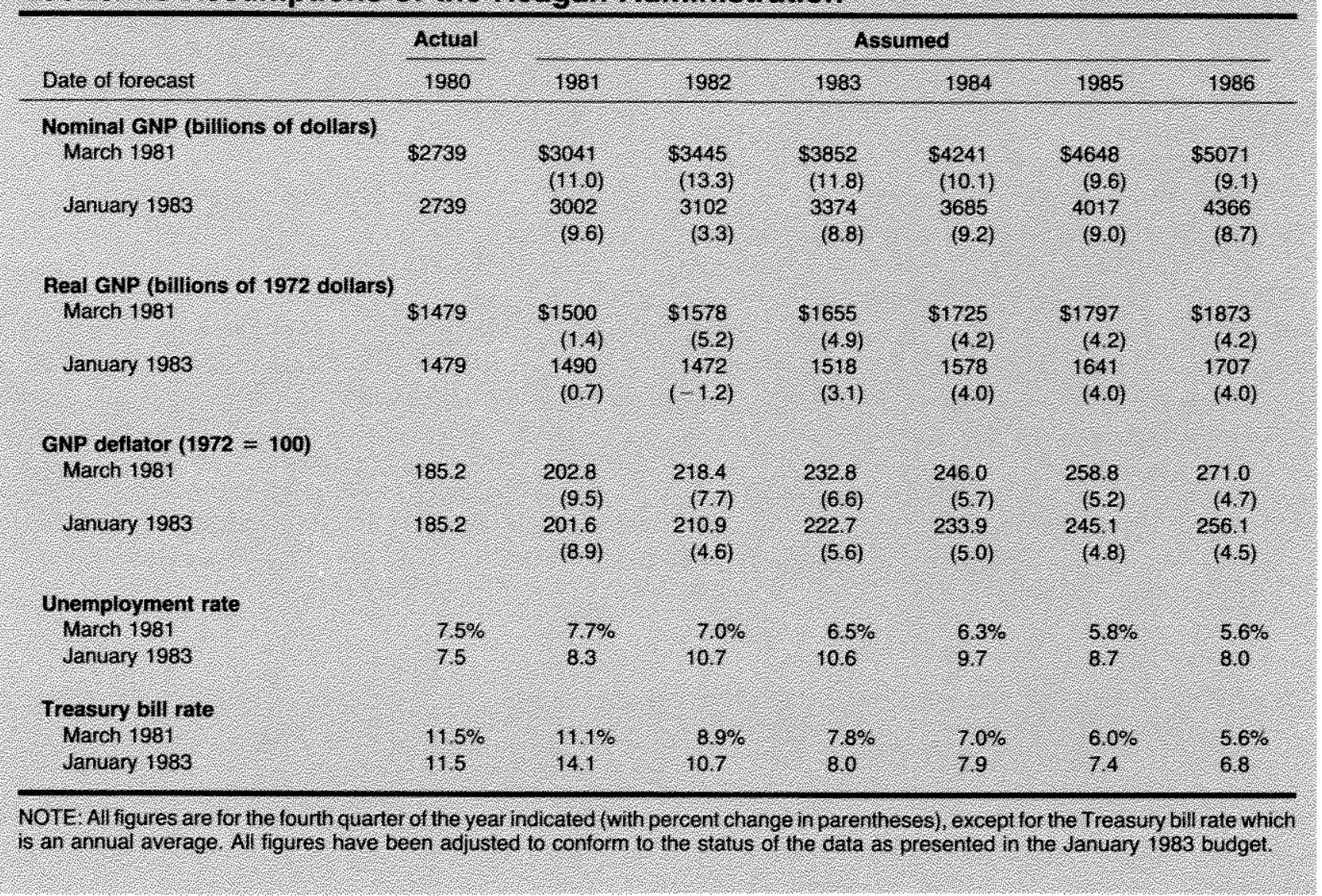

\section{Budget Projections}

The projections for the budget based on the economic assumptions in table 1 are summarized in table 2 . The 1981 budget projected outlays (including offbudget) for 1986 at $\$ 961$ billion. "Targeted" outlays were set at $\$ 912$ billion, but the administration did not specify where the additional cuts were to be made. The 1983 budget projects 1986 outlays at $\$ 999$ billion. This increase from $\$ 961$ to $\$ 999$ billion is roughly the amount by which actual 1982 outlays exceeded the original estimate.

The receipts side of the budget has taken a more dramatic turn since the Reagan administration took office in 1981. The 1981 Reagan budget projected receipts for 1986 at $\$ 940$ billion. Included in this estimate were changes in tax law that reduced receipts by $\$ 218$ billion from what they otherwise would be. Compared to the original Reagan proposals in 1981, total receipts estimates for 1986 have been scaled back by almost another $\$ 100$ billion to $\$ 842$ billion. Without the proposed contingency tax of $\$ 46$ billion, the 1986 receipts estimate would be $\$ 796$ billion.

The original Reagan budget projected the deficit for 1986 at $\$ 21$ billion. The January 1983 budget has revised this estimate of the 1986 deficit to $\$ 157$ billion. Without the contingency tax, the estimate of the 1986 deficit would be $\$ 203$ billion.

\section{AN ANALYSIS OF THE TWO REAGAN BUDGETS}

The revisions in the budget by the Reagan administration appear to be very large, especially when attention is focused on the deficit for fiscal 1986. The January 1983 budget appears to be much more expansionary than the March 1981 budget. As shown in table 1, however, the economic assumptions have also been revised greatly. The questions asked here are to what 
Table 2

\section{Federal Budget Projections of the Reagan Administration} (billions of dollars)

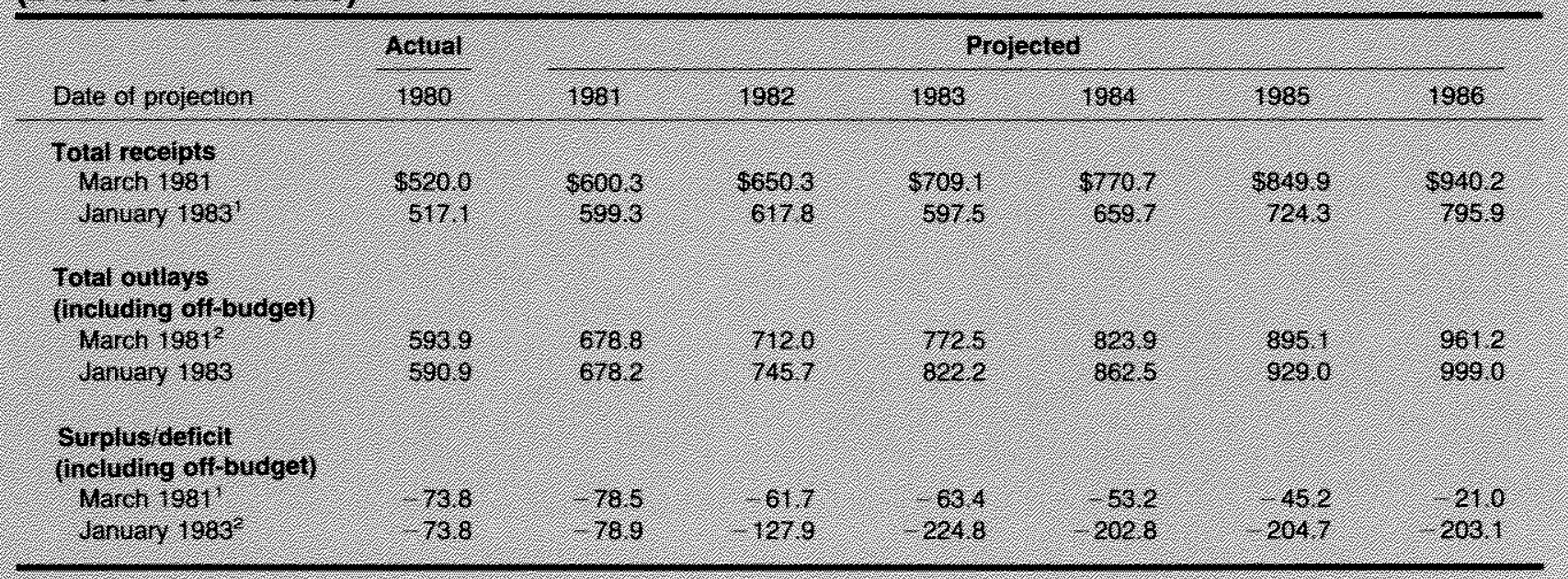

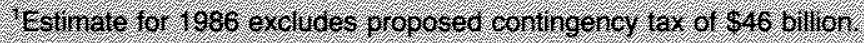

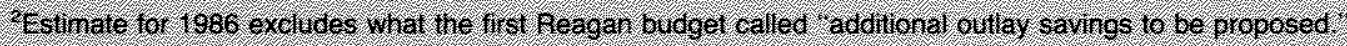

extent have economic assumptions altered the estimates of the deficit in 1986, and to what extent do the revisions reflect program shifts?

\section{Explanation of Procedure}

To apply the analysis of figure 2 to the Reagan budgets, two alternatives are available. One is to convert the 1983 budget estimates to estimates based on the assumptions made in the 1981 budget. The other is to recalculate the 1981 budget on the basis of 1983 assumptions. Either way, the conclusion will be essen tially the same, that is, the relative positions of the two budget lines will be about the same. The alternative chosen here is to compare the 1983 budget with the 1981 budget recalculated with assumptions from the January 1983 budget.

The primary basis for recalculating the 1981 budget is an estimate of the degree of response of outlays and receipts to changes in nominal and real GNP and the price level. These response coefficients were calculated from estimates given in the January 1983 budget. $^{8}$

\footnotetext{
${ }^{8}$ Office of Management and Budget, Budget of the United States Government: Fiscal Year 1984 (January 1983). Also see the appendix to this article. It should be noted that these estimates are approximate and, in the case of outlays, include only the effect of indexed programs.
}

\section{1 vs. 1983 Budget: A Gmphic Simmary}

Figure 3 summarizes the two budgets using the format developed in figure 2. A numerical summary appears in table 3.

Receipts - The solid line in the receipts panel of figure 3 is an estimate from the January 1983 budget of how 1986 receipts vary with real GNP, using the price level as projected in that budget. To compare the receipts line from the March 1981 budget (dashed line), one must recalculate those estimates with the January 1983 assumption about the price level. Once this is done, a comparison of the two receipts lines (the solid line and the dotted line), which can also be thought of as program lines, indicates very little change from 1981 to $1983 .^{9}$

The main reason for the downward revision of receipts from March 1981 to January 1983 is the downward revision of the real GNP assumption. Table 3 divides the total change in receipts into price level

\footnotetext{
${ }^{9}$ Even though figure 2 shows little change in the receipts program from 1981 to 1983 , this does not imply that little has changed. The original Reagan tax plan was modifed somewhat in the legislative embodiment of that plan, the Economic Recovery Tax Act of 1981. The other two major tax acts since 1981 are the Tax Equity and Fiscal Responsibility Act of 1982 and the Highway Revenue Act of 1982.
} 
Figure 3

Economic Activity and the Federal Budget: March 1981 vs. January 1983 Estimates for fiscal 1986

(A)

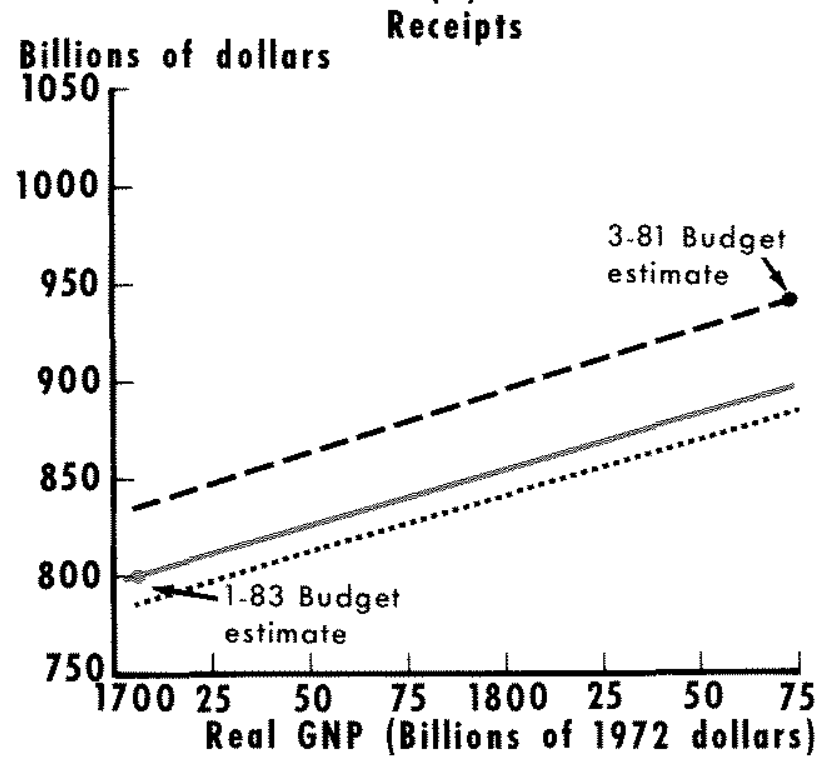

(C)

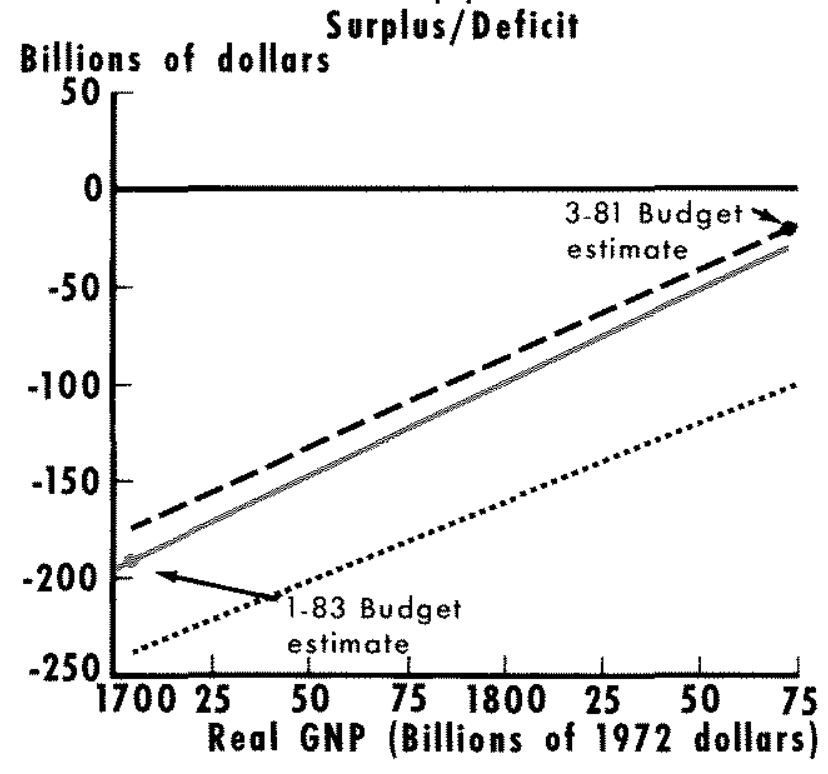

effects, real GNP effects and program shifts. According to table 3 (and table 2), receipts projections for 1986 were revised downward by $\$ 144$ billion between March 1981 and January 1983. Real GNP revisions accounted for $\$ 95$ billion of this change and price level revisions accounted for $\$ 57$ billion. These estimates suggest a small upward program shift for receipts of $\$ 7$ billion between early 1981 and early 1983. Even though the estimates are approximate, it is clear that the program shift was small compared with changes induced by changed economic assumptions. ${ }^{10}$

Outlays - The outlay panel of figure 3 summarizes the effect on fiscal 1986 outlays of revised assumptions

\footnotetext{
${ }^{\text {t0 }}$ Recall that this analysis is being conducted in the absence of the proposed contingency tax. Including that tax would show a sharp upward shift of the receipts line from 1981 to 1983.
} 
Table 3

Decomposition of Changed Budget Estimates for Fiscal 1986 (billions of dollars)

\begin{tabular}{|c|c|c|c|c|}
\hline & $\begin{array}{l}\text { Total change } \\
1981 \text { to } 1088\end{array}$ & $\begin{array}{l}\text { Change gue } \\
\text { to price } \\
\text { lovel }\end{array}$ & 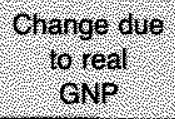 & $\begin{array}{l}\text { ohinge due } \\
\text { lo progrants }\end{array}$ \\
\hline aecepls & $\$, 1443$ & 8.567 & S. 950 & 1. 74 \\
\hline ourtas. & 878 & 247 & 4.442 & 311 \\
\hline surplusioefici & ?. 182 & .81 .4 & 1392 & 38.5 \\
\hline
\end{tabular}

and program shifts from March 1981 to January 1983. A comparison of the solid and dotted lines indicates that the outlay line has shifted down significantly since 1981. According to these estimates, the fiscal 1986 outlay program has been reduced by $\$ 31$ billion since March 1981.

The effect of changed price level assumptions on the March 1981 estimates requires further explanation. Compared to 1981 , price level assumptions were reduced in January 1983. The effect of these revisions was to reduce outlays other than net interest. ${ }^{11}$ However, with the assumed response coefficients, the effect of reduced price level assumptions lowered receipts more than outlays. As a result, deficits were larger and more interest would have to have been paid to finance these deficits. The indirect effect of a lower price level operating via net interest dominates the direct effect on outlays over a five-year period.

The numerical summary in table 3 indicates that changed assumptions about real GNP and the price level "overexplained" the $\$ 38$ billion upward revision of the 1986 outlay projection. In other words, changed economic assumptions indicated an increase of outlays of $\$ 69$ billion, whereas the outlay projection was actually increased by $\$ 38$ billion. Within this framework of analysis, this implies a downward pro-

\footnotetext{
"Note that the discussion is with reference to the effect of changed price level assumptions on the March 1981 estimates of outlays for fiscal 1986
}

gram shift for outlays of $\$ 31$ billion between early 1981 and early 1983.

Surplus/deficit - Figure 3 shows that the budget line shifted upward from March 1981 to January $1983{ }^{12}$ As summarized in table 3 , the 1986 budget line shifted upward by $\$ 39$ billion. On the surface, this shift appears quite large, but relative to the changes attributable to revised economic assumptions, it is quite small.

\section{CONCLUSIONS}

This article has focused on the critical role that economic assumptions play in projections of the federal budget. As an example, estimates for fiscal year 1986 from the Reagan budgets of March 1981 and January 1983 were compared. The analysis indicates that the changes in budget estimates for fiscal 1986 that occurred between March 1981 and January 1983 were primarily influenced by revised economic assumptions and economic developments in 1982 that were considerably different than foreseen. Changes in discretionary fiscal policy played a minor role in accounting for the sizable jump in the projected deficit for 1986 that occurred between the two budget proposals.

\footnotetext{
${ }^{12}$ Note that this shift is still in the planning stage. Realization of the shift requires legislation by the Congress of administration proposals.
} 


\section{Appendix Estimating the Response of the Budget to Alternative Economic Assumptions}

To estimate the effect on budget projections of an alternative set of economic assumptions, the budget was categorized as follows:

1) total receipts excluding earnings of the Federal Reserve System;

2) total outlays (including off-budget) excluding net interest and earnings of the Federal Reserve System;

3) net interest.

The basic source for estimates of the relevant elasticities was the Budget of the United States Government: Fiscal Year 1984 (January 1983), pp. 2-19-2-24.

\section{Total receipts excluding FinS earnings}

The elasticity of receipts with respect to GNP was calculated from the example in the fiscal 1984 budget. The implied coefficients were

$$
\begin{aligned}
\Delta \dot{\mathrm{R}}_{\mathrm{t}}= & .49 \Delta \dot{\mathrm{Y}}_{\mathrm{t}}+.39 \Delta \dot{\mathrm{Y}}_{\mathrm{t}-\mathrm{t}}+.12 \Delta \dot{\mathrm{Y}}_{\mathrm{t}-2}+.08 \Delta \dot{\mathrm{Y}}_{\mathrm{t}-3} \\
& +.07 \Delta \dot{\mathrm{Y}}_{\mathrm{t}-4},
\end{aligned}
$$

where

$\Delta \dot{\mathbf{R}}_{t}=$ change in percent change of receipts in fiscal year $t$;

$\Delta \dot{Y}_{t}=$ change in percent change in nominal GNP in fiscal year $\mathrm{t}$.

\section{Totd oulays exchdivg nol interest ant ERS earnings}

Outlays are responsive to both real growth and inflation. The implied coefficients for the elasticity of outlays with respect to real growth were

$$
\begin{aligned}
\Delta \dot{\mathrm{O}}_{\mathrm{t}}= & -.08 \Delta \dot{\mathrm{X}}_{\mathrm{t}}-.13 \Delta \dot{\mathrm{X}}_{\mathrm{t}-1}-.05 \Delta \dot{\mathrm{X}}_{\mathrm{t}-2}-.06 \Delta \dot{\mathrm{X}}_{\mathrm{t}-3} \\
& -.04 \Delta \dot{\mathrm{X}}_{\mathrm{t}-4}
\end{aligned}
$$

where

$$
\begin{aligned}
\Delta \dot{O}_{t} & =\text { change in percent change of outlays in fiscal year } t \\
\Delta \dot{X}_{\varepsilon} & =\text { change in percent change in real GNP in fiscal } \\
& \text { year } t .
\end{aligned}
$$

The implied coefficients for the elasticity of outlays with respect to inflation were

$$
\begin{aligned}
\Delta \dot{\mathrm{O}}_{\mathrm{t}}= & .01 \Delta \dot{\mathrm{P}}_{\mathrm{t}}+.06 \Delta \dot{\mathrm{P}}_{\mathrm{t}-1}+.09 \Delta \dot{\mathrm{P}}_{t-2}+.05 \Delta \dot{\mathrm{P}}_{\mathrm{t}-3} \\
& +.02 \Delta \dot{\mathrm{P}}_{\mathrm{t}-4}+.02 \Delta \dot{\mathrm{P}}_{\mathrm{t}-5}
\end{aligned}
$$

where

$$
\begin{aligned}
& \Delta \dot{\mathrm{P}}_{\mathrm{t}}=\text { change in percent change in the GNP deflator in } \\
& \text { fiscal year } \mathrm{t} \text {. }
\end{aligned}
$$

These estimates are for indexed program outlays only; excluded are changes that might result from congressional or executive action to maintain real program or benefit levels for discretionary programs.

\section{Net huteresh, surplus/deficit and debt}

To estimate net interest, the surplus/deficit and debt held by the public, the following three-equation system was solved:

1) $I_{t}=I_{t-1}+\left(i_{t}-i_{t}^{m}\right)\left(\frac{1}{2} \alpha_{t} D_{t-1}\right)+i_{t}\left[\frac{1}{2}\left(D_{t}-D_{t-1}\right)\right]$

2) $D_{t}=D_{t-1}-S_{t}+\Delta C_{t}$

3) $S_{t}=R_{t}-O_{t}-I_{t}$,

where

$\mathrm{t}=$ fiscal year (flows are during the year and stocks are end of year);

$\mathrm{I}_{\mathrm{t}}=$ net interest in fiscal year $\mathrm{t}$ (excluding FRS earnings);

$\mathrm{D}_{\mathrm{t}}=$ debt held by the public (including FRS) at the end of fiscal year $t$;

$S_{t} \quad=$ budget surplus;

$\Delta \mathrm{C}_{\mathrm{t}}=$ change in Treasury cash balance;

$\mathbf{R}_{\mathrm{t}}=$ receipts as calculated above;

$\mathrm{O}_{\mathrm{t}}$ = outlays as calculated above;

$i_{t}=$ average of 3 -month Treasury bill and 10-year Treasury note rates;

$\mathrm{i}_{\mathrm{t}}^{\mathrm{m}}$ = average interest rate on debt maturing during period $t$

$\alpha_{\mathrm{t}}=$ proportion of debt maturing in period $\mathrm{t}$. 